\title{
Yield and Protein Content of Sandyland Range Forages as Affected by Three Nitrogen Fertilizers
}

\section{R. D. PETTIT AND DONALD W. DEERING}

Highlight: $A$ west Texas sandyland range site was fertilized with two rates, (30 and $60 \mathrm{~kg} / \mathrm{ha}$ of actual $N$ ) of ammonium nitrate $(A N)$, ammonium sulfate $(A S)$ and ammonium phosphate-sulfate (APS) on June 2, 1972. Yield samples taken in mid-August showed all fertilizer treatments to significantly increase total yields. The $60 \mathrm{~kg} / \mathrm{ha}$ of $N$ treatments of $A S$ and APS produced more herbage than all other fertilizer treatments. Climax decreasers on the site, little bluestem (Schizachyrium scoparium) and sideoats grama (Bouteloua curtipendula), showed less yield response to fertilization than increaser and invader grasses. Crude protein analysis of leaf tissue showed the grasses of the control (ON) to contain significantly less and the grasses treated with $60 \mathrm{~kg} / \mathrm{ha}$ of $N$ as $A N$ to contain more protein than other treatments. Sulfur appears to be more important than phosphorus in increasing yields on this site. Also, range condition should be at least high fair before fertilizer is applied to minimize competition between the desirable and invader plants.

In the Southern High Plains of Texas, rangeland fertilization tests have been restricted to short and mid-grass prairie species. No data are available concerning the effects of fertilizer on sandyland range forages in this area. An increased demand by feedlots for locally produced stocker cattle warrants that higher yields and better quality forage be produced on native ranges. In this area unfertilized rangeland forages seldom contain enough crude protein to meet the maintenance requirements of beef cows (Rodger and Box, 1967).

On a sands range site in western Nebraska $15 \mathrm{lb} /$ acre of $\mathrm{N}$ as $\mathrm{NH}_{4} \mathrm{NO}_{3}$ did not increase forage production (Burzlaff et al., 1968). When 30 and $60 \mathrm{lb} /$ acre of $\mathrm{N}$ were applied, production increased over the control treatment. On a Valentine loamy sand, forage yields were increased 24 to $27 \%$ when low rates of nitrogen and phosphorus were applied (Warnes and Newell, 1969). Mcllvain (1961) agreed that herbage yields on sandyland range sites could be increased by fertilization, but the cost of fertilizer often exceeded the value of the additional forage produced.

Mcllvain's (1961) study confirmed that phosphorus only enhanced forage production if nitrogen was supplied with it. Generally, phosphorus additions alone to rangeland forages do not substantially increase yields (Launchbaugh, 1962; Hull, 1963; McMurphy, 1970; and Vallentine, 1971).

Little data in the Central Plains states are available concerning the effect of sulfur additions on rangeland herbage yields and forage quality. California annual grasslands, however, show dramatic responses to sulfur and nitrogen additions

Authors were assistant professor and graduate research assistant, Department of Range and Wildlife Management, Texas Tech University, Lubbock, at the time the study was made. Donald Deering is currently research associate, Department of Range Science, Texas A\&M University, College Station.

Manuscript received July 2, 1973.
(Walker and Williams, 1963; Martin et al., 1964; Kay, 1966; and Conrad et al., 1966).

The response of early successional grass species to fertilization is often quite different from climax species response (Rice et al., 1960). Decreaser plant composition was increased because of fertilization in central Oklahoma (Graves and McMurphy, 1969). Compositional changes in vegetation as affected by fertilization have been reported by other scientists. Hyder and Bement (1972) postulated that low rates of nitrogen, when applied to early successional stages on "goback" land, could "speed up" succession by causing the red threeawn (Aristida longiseta) stage to be bypassed.

This study was designed to test the effects of three nitrogenous fertilizers upon the crude protein content and yield of important grass species on a sandyland range site in west Texas.

\section{Methods and Procedures}

This research was conducted on a good condition sandyland range site $14.5 \mathrm{~km}$ north of Plains, Texas. This range site, common throughout the Southern High Plains, has been classified as being a portion of the High Plains Bluestem community (Allred, 1956). Climax tall grasses on the site include sand bluestem (Andropogon hallii), little bluestem (Schizachyrium scoparium), and giant dropseed (Sporobolus giganteus), while fall witchgrass (Leptoloma cognatum), sand paspalum (Paspalum setaceum), purple threeawn (Aristida purpurea), sideoats grama (Bouteloua curtipendula), and sand dropseed (Sporobolus cryptandrus) are common. It is rare to find dense stands of tall grasses on this site as grazing has eliminated most of them. Forbs are common on the area as is sand shin oak (Quercus havardii) and sand sagebrush (Artemisia filifolia).

The soil of the study area is Brownfield-Patricia fine sand complex. An A horizon of 92\% sand (12-20 inches thick) overlies a sandy clay loam B horizon with up to $40 \%$ clay. Rates of infiltration and water percolation into these soils are very rapid ( 5 inches $/ / \mathrm{hr}$ ) until water reaches the sub-soil. These soils are usually slightly calcareous with a $\mathrm{pH}$ from 7.0 to 7.5. Their fertility is also considered low (Dittemore and Hyde, 1960). Without plant cover they are highly susceptible to wind erosion.

Climate of the area is warm-temperate and continental. Temperature extremes range from $44^{\circ} \mathrm{C}$ to $-30^{\circ} \mathrm{C}$ with a growing season of nearly 200 days. Precipitation averages 40 $\mathrm{cm} /$ year with extremes of $15 \mathrm{~cm}$ to $58 \mathrm{~cm} /$ year. From June 2 through August 17, 1972, $17 \mathrm{~cm}$ of precipitation were received on the study area.

On June 2,1972,10 $\mathrm{m}^{2}$ plots were broadcast-fertilized with two rates of ammonium nitrate (33.5-0-0), ammonium phosphate-sulfate (16-20-0 with $12 \% \mathrm{~S}$ ), and ammonium sulfate (21-0-0 with $23 \% \mathrm{~S})$. Thirty and $60 \mathrm{~kg} / \mathrm{ha}$ of actual $\mathrm{N}$ were applied in a randomized complete block design. In early August, 1972, the vegetation of three $1 \mathrm{~m}^{2}$ plots was clipped by species at ground level in each treatment plot. Samples were transferred to a drying room and dried 48 hours at $70^{\circ} \mathrm{C}$. Total herbage biomass was determined prior to removing leaf 
Table 1. Herbage yield ( $\mathrm{kg} / \mathrm{ha})$ of each important forage or group of forages as affected by different nitrogen fertilizers on a west Texas sandyland range site.

\begin{tabular}{|c|c|c|c|c|c|c|c|c|}
\hline \multirow[b]{2}{*}{ Species } & \multicolumn{8}{|c|}{ Fertilizer treatments } \\
\hline & Control & $30 \mathrm{AN}^{1}$ & $60 \mathrm{AN}$ & $30 \mathrm{AS}^{1}$ & $60 \mathrm{AS}$ & $30 \mathrm{APS}^{1}$ & 60APS & Average \\
\hline Purple threeawn & 229 & 229 & 191 & 268 & 402 & 382 & 347 & 293 \\
\hline Sideoats grama & 123 & 166 & 152 & 123 & 218 & 104 & 198 & 155 \\
\hline Little bluestem & 126 & 35 & 40 & 189 & 24 & 54 & 218 & 98 \\
\hline Fall witchgrass & 18 & 76 & 48 & 73 & 140 & 26 & 18 & 57 \\
\hline Sand paspalum & 133 & 241 & 191 & 211 & 234 & 188 & 281 & 211 \\
\hline Sand dropseed & 532 & 726 & 766 & 647 & 1309 & 870 & 1153 & 858 \\
\hline Other grasses & 158 & 406 & 697 & 535 & 317 & 438 & 217 & 395 \\
\hline Total grasses & $1319 \mathrm{a}^{2}$ & $1879 \mathrm{bc}$ & $2085 \mathrm{bc}$ & $2046 \mathrm{bc}$ & $2644 \mathrm{~cd}$ & $2062 \mathrm{bc}$ & $2432 \mathrm{~cd}$ & \\
\hline Total shrubs & 589 a & $366 b$ & 391 & $310 b c$ & $244 \mathrm{c}$ & 342 b & $511 \mathrm{a}$ & 393 \\
\hline Total forbs & $158 \mathrm{de}$ & 552 a & $94 \mathrm{e}$ & $248 \mathrm{bcd}$ & 299 & $320 \mathrm{~b}$ & $189 \mathrm{bcde}$ & 266 \\
\hline Total all vegetation & $2066 \mathrm{a}$ & $2797 b$ & $2570 \mathrm{~b}$ & $2604 \mathrm{~b}$ & $3187 \mathrm{c}$ & $2724 \mathrm{~b}$ & $3132 \mathrm{c}$ & \\
\hline
\end{tabular}

${ }^{1}$ Designates ammonium nitrate, ammonium sulphate, and ammonium phosphate-sulfate.

"All cotal yields in rows followed by the same letter are not different at the 0.05 level of significance.

tissues from the important forages for total $\mathrm{N}$ analyses. Leaf samples were ground to pass a 40-mesh screen, then stored in air tight containers for subsequent $\mathrm{N}$ analysis

The micro-Kjeldahl technique was used to analyse $0.1 \mathrm{~g}$ samples for $\mathrm{N}$ content. Six analyses of each species per treatment were conducted to obtain the average crude protein content per treatment and species.

All data were analyzed factorially at the .05 level of significance. Means were compared using Duncan's Multiple Range Test (Steel and Torrie, 1960).

\section{Results and Discussion}

\section{Herbage Production}

All nitrogen fertilizers significantly increased herbage production (Table 1). The $60 \mathrm{~kg} /$ ha of ammonium sulfate (AS) and ammonium phosphate-sulfate (APS) were most effective in increasing yield (Fig. 1). All other rates demonstrated herbage responses that were not significantly different. A marked increase in grass yield was found for all fertilized plots. The $60 \mathrm{~kg} /$ ha of $\mathrm{N}$ as ammonium nitrate (AN) did not produce significantly more grass than the $30 \mathrm{~kg} / \mathrm{ha}$ of this fertilizer.

Forb and shrub yield data did not show as clear and consistent a response to fertilization as the grasses (Table 1).
Thirty $\mathrm{kg} / \mathrm{ha}$ of $\mathrm{N}$ as AN promoted forb yields, whereas the 60 $\mathrm{kg} / \mathrm{ha}$ of $\mathrm{N}$ as $\mathrm{AN}$ produced least forb yield. The control (ON), $30 \mathrm{~kg} / \mathrm{ha}$ of $\mathrm{N}$ as $\Lambda \mathrm{S}$, and $60 \mathrm{~kg} / \mathrm{ha}$ of $\mathrm{N}$ as $\Lambda P S$ gave similar forb yields. Even though no dramatic shrub yield responses were shown, there was a trend indicating fertilization to be detrimental to shrub production.

Of the species analyzed, sand dropseed yield was increased most by fertilization (Table 1). Yield increases varied from 22 to $146 \%$ as a result of fertilization. The $60 \mathrm{~kg} / \mathrm{h}$ a of $\mathrm{N}$ as $\mathrm{AN}$, AS, and APS produced $766 \mathrm{~kg} / \mathrm{ha}, 1309 \mathrm{~kg} / \mathrm{ha}$, and 1153 $\mathrm{kg} / \mathrm{ha}$ of sand dropseed, respectively. This demonstrated that nitrogen alone was not adequate to stimulate maximum herbage response on these soils. The other "increaser" grass species-purple threeawn, fall witchgrass, and sand paspalumdid not respond as markedly to fertilization as did the dropseed. Yields of other grasses which included Eragrostis spp., Cenchrus sp., and other "invaders" increased due to fertilization.

Forb production on this sandyland site may be decreased by nitrogen applications in excess of $60 \mathrm{~kg} / \mathrm{ha}$ of actual $\mathrm{N}$. Mortality was observed in several perennial forbs on this site where over $60 \mathrm{~kg} / \mathrm{ha}$ of $\mathrm{N}$ had been applied. With this
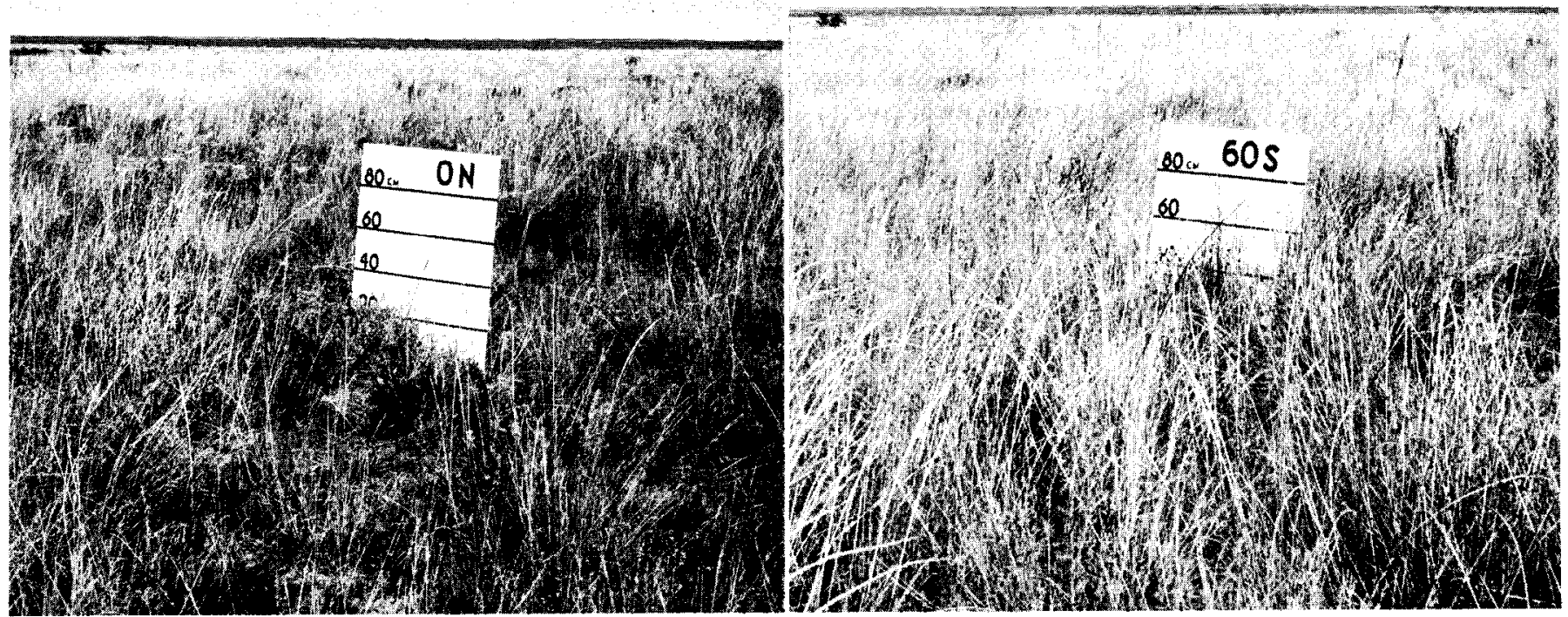

Fig. 1. Typical view of an unfertilized (ON) sandyland range site (left) showing the low vigor of grasses. When $60 \mathrm{~kg}$ of $\mathrm{N} / \mathrm{ha}$ as a mmonium sulfate $(60$ S) was added (right), a marked increase in grass growth, particularly sand dropseed, was noted. 
Table 2. Average crude protein concentration (\%) of important sandyland range forages. All grasses had secdheads exerted and only leaf tissue was analyzed.

\begin{tabular}{|c|c|c|c|c|c|c|c|c|}
\hline \multirow[b]{2}{*}{ Species } & \multicolumn{8}{|c|}{ Treatment ${ }^{1}$} \\
\hline & Control & $30 \mathrm{AN}^{2}$ & $60 \mathrm{AN}$ & $30 \mathrm{AS}^{2}$ & $60 \mathrm{AS}$ & $30 \mathrm{APS}^{2}$ & 60APS & Average \\
\hline Purple threeawn & 8.23 & 12.05 & 10.78 & 9.13 & 9.91 & 8.94 & 9.35 & $9.77 \mathrm{ab}^{3}$ \\
\hline Sideoats grama & 6.90 & 10.49 & 11.13 & 9.52 & 9.03 & 9.06 & 10.19 & $9.47 \mathrm{a}$ \\
\hline Little bluestem & 8.61 & 10.73 & 10.92 & 8.98 & 9.41 & 9.59 & 10.00 & $9.75 \mathrm{ab}$ \\
\hline Fall witchgrass & 7.87 & 10.28 & 12.71 & 12.36 & 10.00 & 9.86 & 12.15 & $10.75 \mathrm{cb}$ \\
\hline Sand paspalum & 7.39 & 11.82 & 12.85 & 12.42 & 12.59 & 9.21 & 10.89 & $11.02 \mathrm{c}$ \\
\hline Sand dropseed & 9.19 & 12.05 & 14.69 & 12.21 & 13.41 & 9.61 & 11.79 & $11.85 \mathrm{c}$ \\
\hline
\end{tabular}

${ }^{1}$ Each value is the mean of 6 analyses/species/treatment.

${ }^{2}$ Designates ammonium nitrate, ammonium sulphate, and ammonium phosphate-sulfate.

${ }^{3}$ Mean crude protein percentages followed by same letter are not different at the 0.05 level of significance.

evidence, it appears that many forbs adapted to sandy soils cannot tolerate a high soil nitrogen content.

\section{Protein Content of Forage}

At the time of harvest crude protein concentration in the leaf tissue of the six grasses analyzed was significantly increased by all fertilizer treatments (Table 2). In the control $(\mathrm{ON})$, crude protein concentration averaged $8.03 \%$ whereas the $30 \mathrm{~kg} / \mathrm{ha}$ of $\mathrm{N}$ and $60 \mathrm{~kg} / \mathrm{ha}$ of $\mathrm{N}$ grasses averaged 10.46 and $11.21 \%$ crude protein, respectively. Per unit of forage, the 60 $\mathrm{kg} / \mathrm{ha}$ of $\mathrm{N}$ as $\mathrm{AN}$ produced significantly higher quality forage. All crude protein concentrations in treatments with sulfur and phosphorus additions were similar.

When considering total quantity of protein produced by each fertilizer treatment, different results were obtained. For the grasses analyzed for crude protein, the control (ON), 30 $\mathrm{AN}, 60 \mathrm{AN}, 30 \mathrm{AS}, 60 \mathrm{AS}, 30 \mathrm{APS}$, and $60 \mathrm{APS}$ treatments produced forage which contained 93, 164, 168, 162, 249, 150, and $237 \mathrm{~kg} / \mathrm{ha}$ of protein. These data confirm that sulfur and phosphorus with $60 \mathrm{~kg}$ of N/ha are essential to promote a high total crude protein yield on this range site.

Although fertilization increased the crude protein content of the leaves of the grasses analyzed, each species responded to fertilization differently. All grasses, with the exception of purple threeawn, contained considerably more crude protein than did sideoats grama and little bluestem.

\section{Conclusions}

This research has demonstrated that fertilization of sandyland range forages in west Texas can significantly increase yields and crude protein concentration of the herbage. The importance of range condition as related to fertilizer response, however, cannot be overemphasized. Fertilization of low or even fair condition sandyland ranges facilitates vigorous growth of undesirable plants such as sandbur (Cenchrus spp.), false buffalograss (Munroa squarrosa) and scveral annual lovegrasses (Eragrostis spp.). By promoting this undesirable plant growth, the better perennial forages are placed under additional stress because of insufficient soil water.

In addition, we speculate that if long dry periods follow the fertilizer application, nitrogen may be lost from the system through volatilization. Pilot fertilizer studies initiated in 1971, characterized by a very dry and hot growing season, showed no herbage increases with late summer precipitation. No response was noted in 1972 on these plots.

In summary, nitrogen applications alone on this sandyland range site are not adequate to produce a high total yield of crude protein. If the landowner was interested in increasing yields yet maintaining a satisfactory quality forage, we would recommended an application of $30 \mathrm{~kg} / \mathrm{ha}$ of $\mathrm{N}$ as ammonium sulfate. It is questionable whether phosphorus additions are beneficial on this site. Further testing, specifically on the role of sulfur nutrition as related to plant growth in this area, needs to be completed before concrete fertilizer recommendations can be made.

\section{Literature Cited}

Allred, B. W. 1956. Mixed Prairics in Texas. In Grasslands of the Great Plains. Johnson Publ. Col, Lincoln, Nebraska. 395 p.

Burzlaff, D. F., G. Fick, and L. Rittenhouse. 1968. Effect of nitrogen fertilization on certain factors of a western Nebraska range ecosystem. J. Range Manage. 21:21-24.

Conrad, C. Eugene, E. J. Woolfolk, and Don A. Duncan. 1966. Fertilization and management implications on California annualplant range. J. Range Manage. 19:26.

Dittemore, W. H., and H. W. Hyde. 1964. Soil Survey of Yoakum County, Texas. Soil Conservation Service. U. S. Dep. Agr. Series 1960, No. 15.

Graves, James E., and Wilfred E. McMurphy. 1969. Burning and fertilization for range improvement in central Oklahoma. J. Range Manage. 22:165-168.

Hull, A. C. 1963. Fertilization of seeded grasses on mountainous rangelands in northeastern $U$ tah and southeastern Idaho. J. Range Manage. 16:306-312.

Hyder, D. N., and R. E. Bement. 1972. Controlling red threeawn on abandoned cropland with ammonium nitrate. J. Range Manage. $25: 443-446$.

Kay, Burgess L. 1966. Fertilization of cheatgrass ranges in California. J. Range Manage. 19:217-220.

Launchbaugh, J. L. 1962. Soil fertility investigations and effects of commercial fertilizers on reseeded vegetation in west-central Kansas. J. Range Manage. 15:27-34.

Martin, W. E., Cecil Pierce, and V. P. Osterli. 1964. Differential nitrogen response of annual and perennial grasses. J. Kange Manage. 17:67-68.

Mcllvain, E. H. 1961. Summary of range and pasture fertilization studies in the Southern Great Plains. U.S. Dep. Agr., Agr. Res. Serv., Woodward, Oklahoma. Mimeo.

McMurphy, Wilfred E. 1970. Fertilization and deferment of a native hay meadow in north central Oklahoma. Okla. Agr. Exp. Sta. Bull. 678.

Rice, E. L., Wm. T. Penfound, and L. M. Rohrbaugh. 1960. Seed dispersal and mineral nutrition in succession in abandoned fields in central Oklahoma. Ecology 41:224-228.

Rodger, J. Daniel, and Thadis W. Box. 1967. Seasonal protein content of four Southern Mixed Prairie grasses. J. Range Manage. 20:177-178.

Steel, R. G. D., and J. H. Torrie. 1960. Principles and procedures of Statistics. McGraw-Hill, New York, N. Y. 481 p.

Vallentine, John F. 1971. Range Developments and Improvements. Brigham Young Univ. Press, Provo, Utah. 516 p.

Walker, Charles F., and William A. Williams. 1963. Responses of annual-type range vegetation to sulfur fertilization. J. Range Manage. 16:64-69.

Warnes, D. D., and L. C. Newell. 1969. Establishment and yield responses of warm-season grass strains to fertilization. J. Range Manage. 22:235-240. 